\title{
A Leucistic Indian Rock Python, Python molurus (Linnaeus 1758), from Andhra Pradesh, India
}

\author{
B. Laxmi Narayana ${ }^{1}$, V. Vasudeva Rao ${ }^{1}$, and V. Nagulu ${ }^{2}$ \\ ${ }^{1}$ All India Network Project on Vertebrate Pest Management, PJTS Agricultural University, Rajendranagar, Hyderabad-500030, Telangana, India \\ (narayana.laxmi8@gmail.com) \\ ${ }^{2}$ Department of Zoology (Rtd. Prof.), Osmania University, Hyderabad, 500007, India
}

$\mathrm{T}$ he Indian Rock Python, Python molurus (Linnaeus 1758), is a large non-venomous snake found in much of tropical and subtropical southern and southeastern Asia. The species is widely distributed on the Indian Subcontinent (Smith 1943; Das 2002; Whitaker and Captain 2004, 2008) and has been categorized as Schedule-I in the Indian Wildlife Protection Act of 1972, is listed in CITES Appendix I (CITES 2016), but has not been assessed for the IUCN Red List since the recent elevation of $P$. bivittatus (Jacobs et al. 2009), which had been considered a subspecies of $P$. molurus.

During faunal studies from June 2014 to December 2015 in the Srikakulam District, Andhra Pradesh, we encountered several dead individuals killed by local villagers. One of the snakes (Fig. 1) found on 9 September 2015 near Laxmipuram

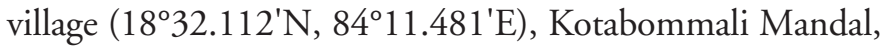
Tekkali Range, Srikakulam District, Andhra Pradesh, along the eastern Indian coast (Fig. 2) was unusually colored. This evidently leucistic snake was about $1.5 \mathrm{~m}$ in total length and milky-white except for gold and gray diamond-shaped markings on the dorsum. This was in sharp contrast with the prevalent color pattern of the species, which is whitish or yellowish with blotches ranging from tan to dark brown, often varying with terrain and habitat. Whitaker (1987) indicated that snakes from the upland forests of the Western Ghats and Assam are darker, whereas those from the Deccan Plateau and the eastern coast are usually lighter.

Leucism, a reduction in multiple types of pigments, is a condition expressed as a partial loss of pigmentation in an animal resulting in white, pale, or patchy coloration of the skin, hair, feathers, scales, or cuticle, but not the eyes (e.g., Lillywhite 2008). Leucism often is confused or equated with albinism (total lack of all pigments) or amelanism (lack of melanin but presence of other pigments). Leucistic, amelanistic, and albino individuals are rare in nature (e.g., Dobosz et al. 2008), presumably due to reductions in fitness largely attributable to deficient crypsis, although captive-bred animals are abundant (e.g., a Google ${ }^{\Theta}$ search for "albino pythons" generated over 400,000 results).

The destruction of such an unusual snake was regrettable, but sadly reflects the attitudes of many Indians. Guptha (2013) advocated the conservation of Indian Rock Pythons, noting an urgent need to conserve the species and create an awareness among local people about pythons and other wildlife in and around the Seshachalam Forest of Andhra Pradesh.

\section{Acknowledgements}

We thank the Indian Council of Agricultural Research for providing necessary facilities. The All India Network Project on Vertebrate Pest Management; Prof. Jayashankar, Telangana State Agricultural University, Telangana; East Coast Energy Private Ltd., Hyderabad; and the Andhra Pradesh Forest Department provided support in the field.

\section{Literature Cited}

CITES (Convention on International Trade in Endangered Species of Wild Fauna and Flora). 2016. Appendices. <https://cites.org/eng/app/appendices.php>.

Das, I. 2002. A Photographic Guide to Snakes and Other Reptiles of India. New Holland Publishers, London, UK.

Dobosz, B.S., K. Kohlmann, K. Goryczko, and H. Kuzminski. 2008. Growth and vitality in yellow forms of rainbow trout. Journal of Applied Ichthyology 16: 117-20.

Guptha, M.B. 2013. Need for conservation of Indian Rock Python (Python molurus) (Linnaeus 1758). World Journal of Zoology 8: 126-126.

Jacobs, H.J., Auliya, M. and Böhme, W. 2009. On the taxonomy of the Burmese Python, Python molurus bivittatus Kuhl, 1820, specifically on the Sulawesi population. Sauria 31(3): 5-11.

Lillywhite, H.B. 2008. Dictionary of Herpetology. Krieger Publishing Co., Malabar, Florida.

Smith, M.A. 1943. The Fauna of British India, Ceylon and Burma, Including the Whole of the Indo-Chinese Sub-region. Reptilia and Amphibia. Vol. III.Serpentes. Taylor and Francis, London, UK.

Whitaker, R. 1987. Common Indian Snakes. A Field Guide. Macmillan Company of India Ltd., Chennai, India.

Whitaker, R. and A. Captain. 2004. Snakes of India. The Field Guide. Draco Books, Chennai, India.

Whitaker, R. and A. Captain. 2008. Snakes of India. The Field Guide. Draco Books, Chennai, India. 

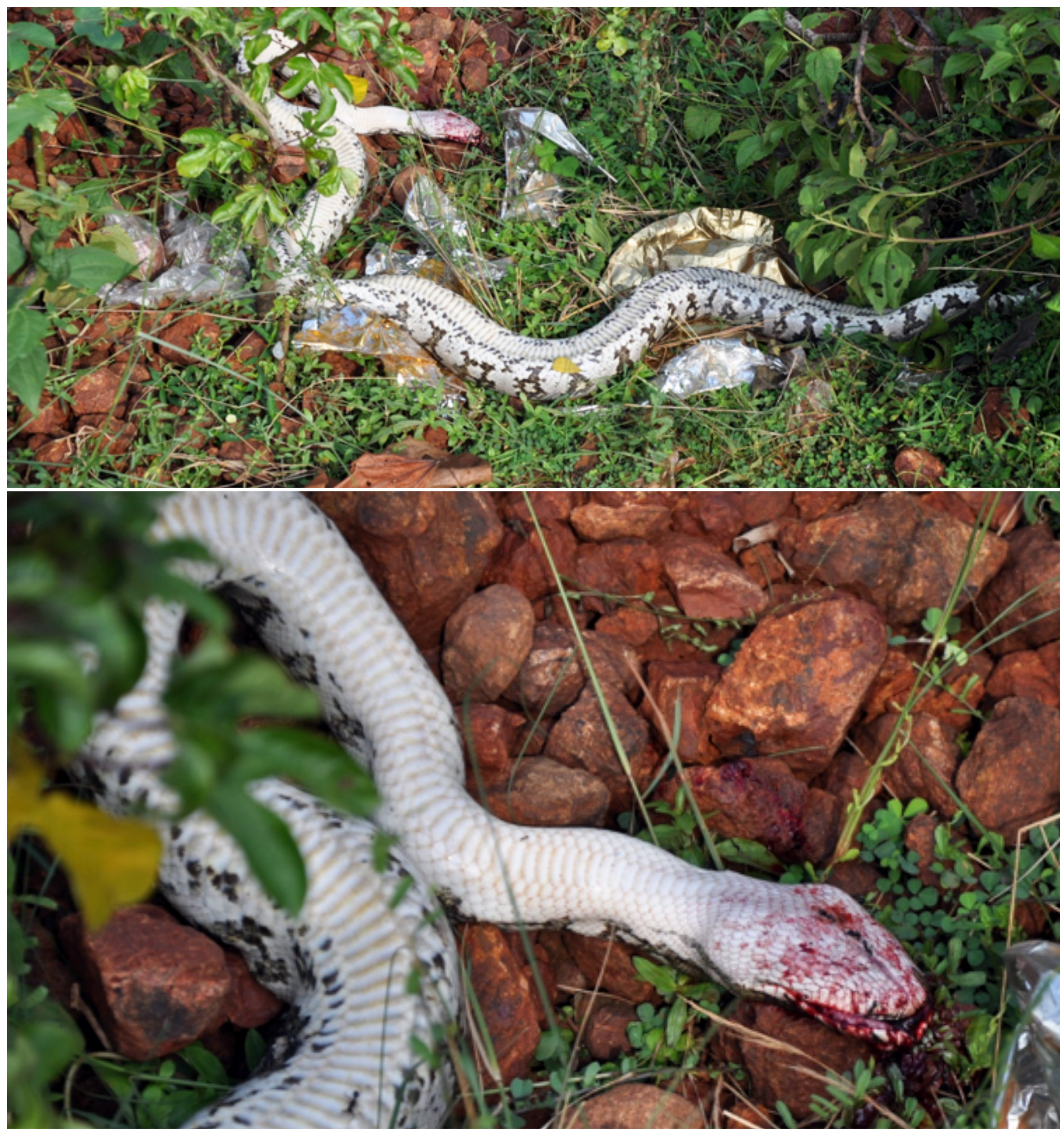

Fig. 1. Leucistic Indian Rock Python (Python molurus) killed by local villagers at Laxmipuram, Srikakulam, Andhra Pradesh, India. Photographs by the senior author. 


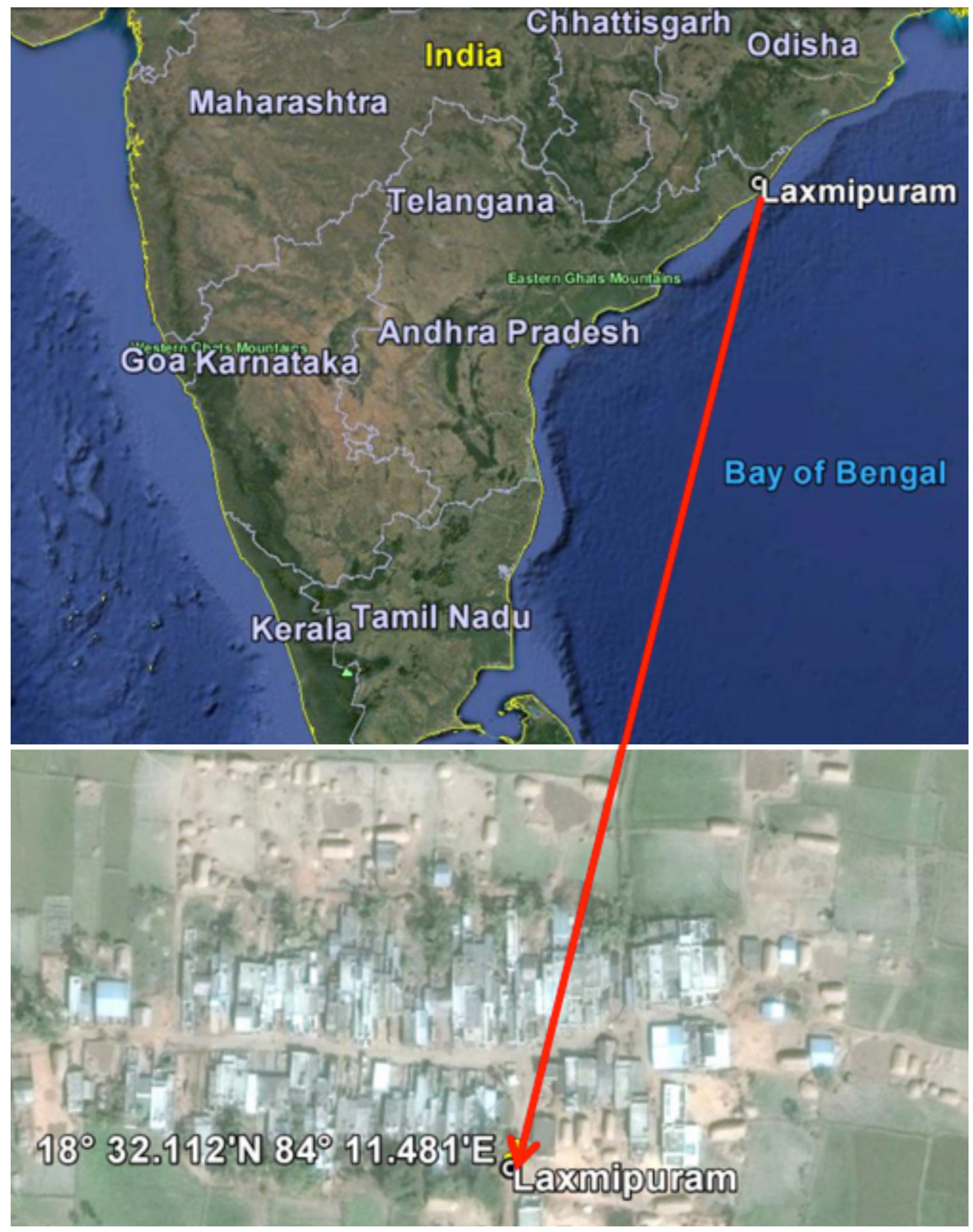

Fig. 2. Google Earth(C) maps showing the location where the leucistic Indian Rock Python (Python molurus) was found in Laxmipuram, Srikakulam, India. 